\title{
Investigating the Effectiveness of Leadership Styles on Instructional Leadership and Teachers Job Expectancy in Kingdom of Bahrain
}

\author{
Sabah Hejres $^{1, *}$, Ashley Braganza ${ }^{2}$, Tillai Aldabi ${ }^{3}$ \\ ${ }^{1} \mathrm{PhD}$ Scholar in Management, Brunel University, UK \\ ${ }^{2}$ Professor of Organizational and Transformation Brunel Business University \\ ${ }^{3}$ Senior Lecturer Brunel Business University \\ *Corresponding author: sabah1966@hotmail.com
}

\begin{abstract}
The purpose of this study is to investigate the effective of the four leadership styles (directive, supportive, participative, and achievement-oriented) on instructional leadership and teachers job expectancies. However, many schools lack a strong principal as instructional leader. Principals have to transform their practices from managerial to instructional emphasis. Principals need to exercise their leadership by attributing the leadership styles in their role and character, or their role will merely deliver an administrative persona that can only be fit to an administrative area. Furthermore, principal play an important role in promote teachers' performance and satisfaction which has declined to its lowest point. The study reports the findings from a survey of 536 subjects of teachers, principals and senior chiefs at various levels of primary, elementary and secondary schools across Kingdom of Bahrain. In addition qualitative method using a focus group interview was conducted of senior chiefs. Simple Regression analysis identifies the relation of leadership styles effect on instructional leadership and job expectancies. The findings contribute to practical implementation of conduct a significant relation between instructional leadership and the four leadership styles. Job expectancy effected by the concept of Transactional Leadership. Distributive leadership contributes to decrees of principal managerial work. The supportive leadership style is most prevalent among instructional leadership and males have less interest in applying leadership styles in Kingdom of Bahrain. All the hypotheses were accepted and the null hypothesis was rejected.
\end{abstract}

Keywords: instructional leadership, leadership styles, job expectancy

Cite This Article: Sabah Hejres, Ashley Braganza, and Tillai Aldabi, "Investigating the Effectiveness of Leadership Styles on Instructional Leadership and Teachers Job Expectancy in Kingdom of Bahrain.” American Journal of Educational Research, vol. 5, no. 7 (2017): 694-709. doi: 10.12691/education-5-7-2.

\section{Introduction}

The concept of leadership is broad and very expansive. It has been associated over decades with various leadership styles and theories such as transactional and transformational leadership [60], learning-centered leadership [54], emotional intelligence [19] and much more. Theoretically, the field still has room for further comparisons and correlations when regarding the numerous leadership types [48]. The researcher deliberately contributes to further research in order to find and form stronger relationships and comparisons between specific leadership theories.

Instructional leadership is a type of leadership that has been thought traditionally as one of the means to communicate high expectations for teachers and students, supervising teaching and learning methods, monitoring assessment and student progress, coordinating the school's curriculum, promoting a climate for learning, and creating a supportive work environment [39]. Leadership is what “increases the school's capacity for improving teachers' instructional capacity" ([26], p. 658). According to Goddard, Goddard, Sook Kim, \& Miller, [17], principals' instructional leadership may support , to a degree, teachers working together to improve instruction, and together leadership and teachers' collaboration may contribute to school effectiveness by strengthening collective efficacy beliefs. However, the lack of specific factors in the context of instructional leadership concept causes a misunderstanding of leadership. [42]. Principals as instructional leaders often fall into the trap of management practices, which hinders them from their true potentials as instructional leaders. According to Barnes, Camburn, Sanders, \& Sebastian, [3], "Principals have to transform their practices from managerial to instructional emphasis” p.273. Principals need to exercise their leadership by attributing the leadership styles in their role and character, or their role will merely deliver an administrative persona that can only be fit to an administrative area. According to Stein [56] "If we are truly serious about equipping our students to compete globally then we need to locate and train institutional leaders rather than managers" ([56], p.29).

This study aim to investigate the effectiveness of leadership styles when rooted in instructional leader and 
impact on the teacher performance. According to Kingdom of Bahrain especially after the findings of the Kingdom's National Authority of Qualifications \& Quality Assurance (QAAET) Annual Report 2014 which claims a lack of quality and qualification in many educational institutes. More than half of the schools have got an evaluation of : «satisfactory» or «inappropriate» in school's leadership and the reason for this evaluation is a lack of effective school leadership processes in the field of self-evaluation, and strategic planning based on high goals and standards to meet the challenges faced by teachers performance.

The teachers performance depend to the extent of the effort that been done whether or not to be rewarded. According to House and Dessler [28] was used for this study to measure job expectancies (I) and expectancy (II), both of these scales were found to have adequate reliability. Expectancy (I) is defined as; subordinates expect that expended efforts will lead to effective performance. Expectancy (II) is defined as subordinates expect that effective performances will lead to rewarding. Therefore, this study assume that instructional leadership play an effective role on teachers performance when consider the effect of leadership styles.

\section{Literature Review}

Coupled with the increased accountability of schools in an outcome-based era, research on instructional leadership has experienced a marked growth over the last three recent decades. The requirement of principals to assume central responsibility for instructional leadership pervades education systems throughout the world [21,22]. According to Stronge, Richard \& Catano, [57] suggests "nothing in the principal's role is more important for ensuring successful school outcome than effective instructional leadership” (p.13). In order to meet the demands of the 21st century, principals play a more dynamic role in overseeing instructional active leadership ties. principals are considered to be instructional leaders $[9,36,44]$.

Instructional leadership skills are important and has been firmly established in many research and reflected in standards applied in the Education Leadership Programs Policy Board for Educational Administration (National [NPBEA], 2002). However, it was also noticed that effective schools that have instructional leader principals who focus more on curriculum, the quality instruction of teaching and learning and less on managerial tasks, have made instructional leadership the dominant paradigm for school leaders [25,31].

According to Marks \& Printy [39] instructional leadership is about dynamic collaboration between the principal and teachers when regarding curricular instructional, and assist in matters that would further teaching and learning.
According to Situmorang [53] found that an instructional leader has a positive direct effect on teachers. Calik, Sezgin, Kavgaci, \& Kilinc, [10] stated that instructional leadership and leadership activities help focus on teaching and learning, including giving teachers feedback on performance. Furthermore, the Wallace Foundation (2010) commissioned a study which found that "district policies and practices focused on instruction are sufficiently powerful that they can be felt by teachers as an animating force behind strong, focused leadership by principals” (p. 203).

Hallinger's [23] reports that an instructional leader principal is who focuses on curriculum, teaching and learning, work directly and provide feedback to teachers on classroom performance using a variety of means. Principals also work to define the school's mission, manage the instructional program, and promote a positive school learning environment. Scholars generally agree that instructional leadership involves principals working intensively and continuously with teachers to examine evidence of the quality of their teaching and to use that evidence to improve their teaching methods. [34,40,62]. According to Townsend [59], higher or lower levels of teachers' quality depends on the quality of the principal. Therefore, the connection between instructional leadership and classroom instruction indicates outcome, including teacher's high job expectations and an instruction-based school climate [58].

The prevalent logic calls for an instructional leader to establish relationships with teachers, focus on and guide teachers to improve the teaching and learning process based on teachers performance [50].

The study aim to invistegate the collabration relationship between teachers and Through a school leadership supported by leadership styles. Path goal theory is theoretical concept that has been recommended to enhance the role of principal as instructional leader. According to Ezzat, Agogué, Le Masson, \& Weil, [15] links between instructional leadership that related to Path-Goal Leadership Theory. Moreover, Nisa (2003) which recommends applying instructional leadership along with the four leadership styles in order to conduct studies regarding the impact of educational institutes on teachers classroom performance.

According to Knight et, al. [30] Path-Goal Leadership Theory consists of four leadership styles: Directive, Supportive, Participative, Achievement -oriented DSPA. Knight suggests that effective leaders direct followers' behavior by changing followers' perceptions of the relationship between behaviors and outcomes. Path-goal Theory of leadership is a situational theory based on the assumption that effective leaders' behavior has a positive impact on subordinates' job s expectancy (House, 1971).

Path-Goal Leadership shown in below Figure 1 consists of Directive, Supportive, Participative, and Achievement -oriented impact on subordinate outcomes.

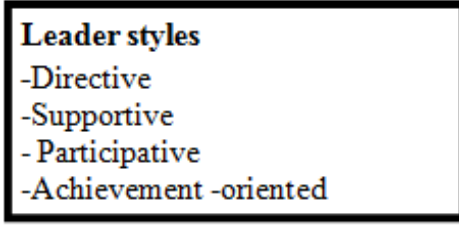

Subordinate outcomes

Job Expectancy 
Based on previous literature review, the researcher connects a link between Path-Goal Leadership theory and Instructional leadership to add more comparisons and association between theory and practice. Each leadership styles faces at the other side a principal behavior as instructional leader according to comparisons analysis, the researcher presents each leadership style associated with instructional leadership roles based on literature review in order to establish criteria to give a comprehensive aspect of comparisons and linkages.

The comparisons analysis below the overlapping behavior between instructional leadership and the theory, the analysis came out by integrated factors. There are factors that can interact with this relationship to establish principal's behavior as instructional leader. The four leadership styles (DSPA) are critical factors in the success of a instructional leadership (IL), they improve initiatives and motivate the function of principals to form a more dynamic collaborative relationship, to help teachers clarify instructional goals and work collaboratively in order to improve teaching and learning. Instructional leaders assume the impact on teachers' expectancy effectively. Thus, principals work with teachers collaboratively as well as help them improve and clarify teaching and learning processes to meet aspired goals.

\subsection{The Linkage between Path Goal Theory and Instructional Leadership.}

The researcher assumes that there is a linkage between path goal theory and instructional leadership.

\subsubsection{Instructional Leadership and Leadership Styles DSPA}

First: In the term of Directive style, Clarifies expectations and gives specific guidance to accomplish the desired expectations based on performance standards and organisational rules [29,37,42]. While in the term of Direct or indirect approach, of instructional leadership , direct (focused on improving teaching) and indirect (focused on creating the conditions for optimal teaching and learning). Direct instructional leadership is focused on the quality of teacher practices, curriculum and assessment. Indirect instructional leadership creates the conditions for good teaching and teacher learning by insuring that school policies, routines, resourcing and other management decisions support and required high-quality learning, teaching and teacher learning. An indirect effect of the principals role on student achievement [35].

Second: Supportive style, Creates a friendly climate, and verbally recognizes achievement of subordinates in a rewarding modus, with respect, treating everyone equally, and show concern for well-being (Negron 2008; House, 1971). In the term of instructional leadership -Supportive approach, supporting collaboration, supporting and supervising teaching in learning groups or individuals, supportive environment. Also providing the occasions for dialogue and coaching [5].

Third: Participative style: Takes on consultative behaviours, such as soliciting subordinates for suggestions prior to making a final decision, albeit, they retain final decision authority [29]. Participative approach in case of instructional leadership, a shared vision with all the members of the school community for improving student learning evokes and supports teacher's learning models, facilitate and participates in collaborative processes. In successful schools, principals promote the values of care and equity within the school and its decision-making process [32].

Fourth: Achievement - oriented style: Sets challenging goals, expects subordinates to perform at their highest level, continuously seeks improvement in performance and shows a high degree of confidence that the subordinates will assume responsibility, put forth effort and accomplish challenging goals' [29]. Achievement - oriented approach in the term of instructional leadership, the principals are both people-centered and achievement-oriented, they also establish a strong, achievement-oriented school culture and clear expectations [1,13].

\subsubsection{Job expectancy by Path Goal Theory}

In terms of job expectancies JS, expectancy attitudes were found to be significantly related to some measures of efforts and performances [33]. Job expectancies scale developed by House and Dessler [28] was used for this study to measure job expectancies(I) and expectancy(II), See Figure 2 Both of these scales were found to have adequate reliability. Expectancy (I) is defined as; subordinates expect that expended efforts will lead to effective performance. Expectancy (II) is defined as subordinates expect that effective performances will lead to rewarding [33]. According to Richard [49] Path-Goal theory is a cognitive approach to understand motivation where subordinates calculate effort-to-performance and performance-to-outcome probabilities.

This study fit model above to the research model by the following in Figure 3 showing the framework of this study began when principals as instructional leaders adopted each of these leadership styles and utilized them as behavior enhancements to find the extant of each leadership style, as well as to emphasize and refined advancements of the role of an instructional leader. The researcher brings instructional leadership criteria of each leadership style; directive, supportive; participative and achievement- oriented DSPA as factors and compromise in accordance with previous studies to find to what extent does this relation effects instructional leaders.

\section{The Model of the Study and Hypothesis Development}

The model below bring all the variables and connect the element in such a relation propose as the follow;

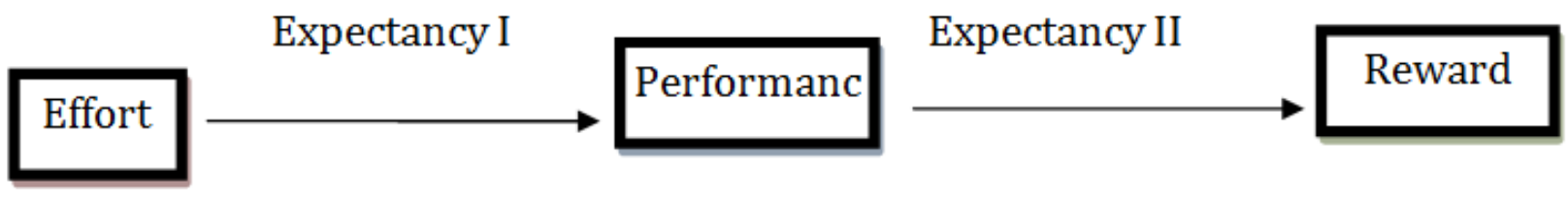

Figure 2. Job expectancy by House and Dessler [28] 


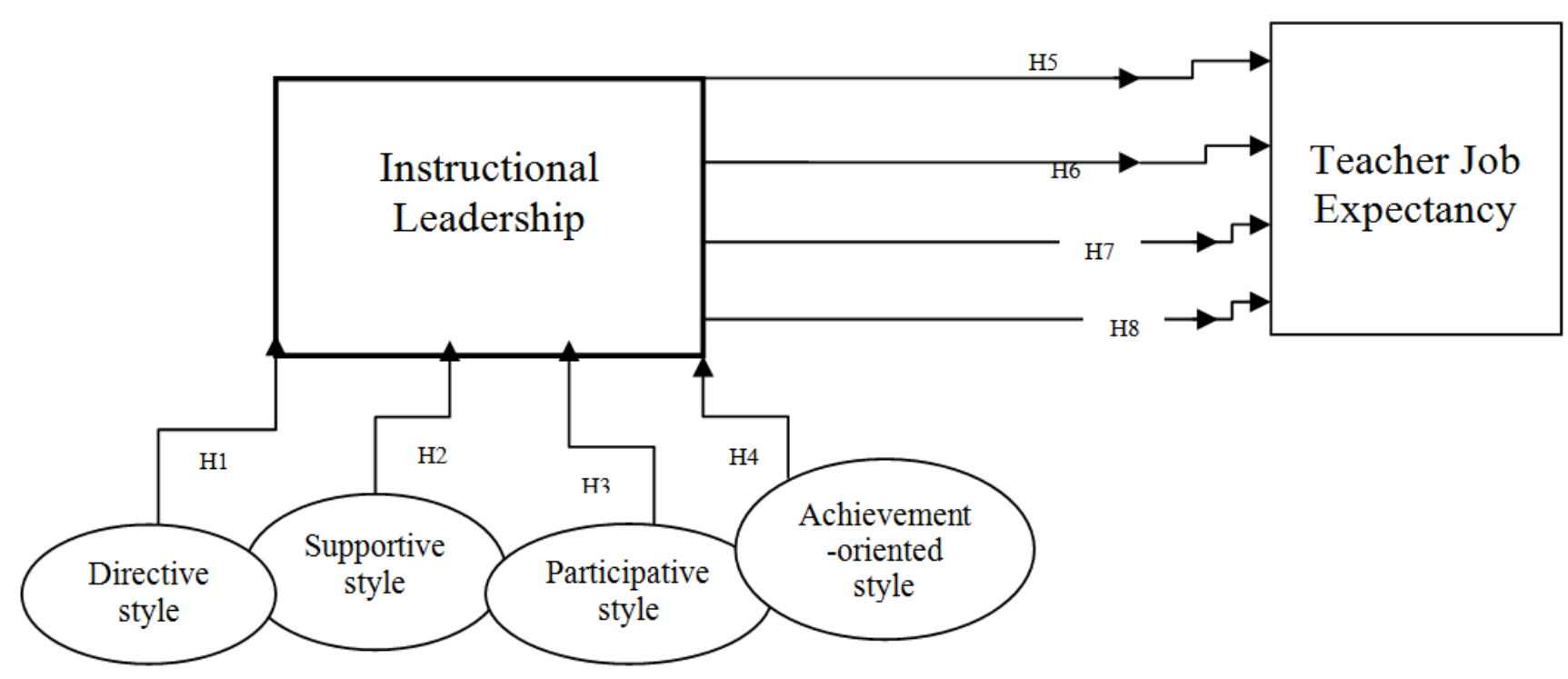

Figure 3. DSPA effect on the relationship between instructional leadership and teachers job expectancy

Few significant studies mention about the relationship between leadership styles DSPA and instructional leadership. This study for first time used each leadership styles directive, supportive, participative, achievementoriented to examines the effectiveness of instructional leadership and impact on job expectancy. Principals as instructional leaders need to transfer the practice and to exercise their leadership by attributing the leadership styles DSPA in their role and behavior otherwise their role will merely deliver an administrative area. The researcher assumes from the literature review that there is a relationship between instructional leadership approach and Leadership styles DSPA that has significant impact on teacher job expectancy which resulting the following research hypothesis:

$\mathrm{H}_{1}$ :There is an effective relation between directive leadership style (DLS) and instructional leadership (IL).

${ }_{\mathrm{H} 2}$ :There is an effective relation between supportive leadership style (SLS) and instructional leadership (IL)

${ }_{\mathrm{H} 3}$ :There is an effective relation between participative leadership style (PLS) and instructional leadership (IL).

${ }_{\mathrm{H} 4}$ :There is an effective relation between achievementoriented leadership style (ALS) and instructional leadership (IL).

H5: There is an effective relationship of directive leadership styles on the relationship between instructional leadership and job expectancy.

H6: There is an effective relationship of supportive leadership styles on the relationship between instructional leadership and job expectancy.

$\mathrm{H}_{7}$ : There is an effective relationship of participative leadership styles on the relationship between instructional leadership and job expectancy.

н8: There is an effective relationship of achievementoriented leadership styles on the relationship between instructional leadership and job expectancy.

\section{Methodology}

This study uses mixed research design of quantitative methods and a focus group of qualitative approach. Quantitative research methods were developed originally within the natural sciences to study natural phenomena. Quantitative research can be defined as a research strategy that emphasises quantification in data collection and analysis [8]. The qualitative research is an interpretive and naturalistic approach. Hoberg (1999) states that qualitative research is useful when researchers intend to gain a deeper understanding of human phenomena, as well as to investigate the given meaning of events that people experience (p.51).

The interpretation is based on the view and attitudes of the participants (principals, teachers and senior chief) towards principals' behaviour as instructional leaders when related to the four leadership styles (DSPA) and teacher job expectancy.

\subsection{Validity}

Validity tests an assessments of how well an instrument measures the particular concept it is intended to measure. Validity is concerned with whether we measure the right concept properly [51]. This study uses a survey to investigate the relation of leadership styles on instructional leadership and teacher job expectancy. The survey measures what it is intended for when validity is applied to it [14]. This study is considered to be the degree to which the tool measures what it claims to measure; and in this case, the validity is an equivalent to accuracy. Therefore, to further support validity, the researcher adopted mixed methods of quantitative approach (questionnaires) and qualitative approach (focus group) to define and reveal several effective aspects of leadership styles on the relationship between instructional leadership and teachers job expectancy this include the three school level primary, intermediate, secondary schools.

The pilot survey measured the impact of the four leadership styles (DSPA) on the relationship between instructional leadership and teachers job expectancy. The results indicate statistic significant of DSPA leadership styles engage in promoting the role of principals as instructional leaders and hence affect of job expectancy. Principals and teachers who participated in the survey stated that they understood the questions in the survey instrument and that there were no ambiguities. Therefore, 
the main survey starts with clarifies each leadership style concept based on the criteria that links between Path Goal theory and Instructional Leadership in each section. This researcher examined the findings from the data analysis and found that the survey measured what it was designed for.

\subsection{Reliability}

Reliability refers to stability and consistency of measurement of the concept [51]. Reliability in quantitative research, refers to the consistency in results conducted by different researchers or a single researcher throughout the time [6]. According to Yin [63], reliability requires researchers to follow the same process when repeating the same survey.

A previous form of the questionnaire was evaluated by a panel of three leadership and statistics experts from professor with expertise in the Ministry of Education (MOE) in The Kingdom of Bahrain. To ensure validity, a questionnaire was adopted from multicultural educational survey [7].

The main questionnaire utilizes a 5- point Likert scale. The researcher distributed the main survey to public school district employees in the Kingdom of Bahrain to collect their perceptions and opinions. illustrates the number of participants from senior chiefs, principals, and teachers size is 536. The population and the samples of schools in Kingdom of Bahrain. See Appendix A.

Table 1. Number of participants by senior chiefs, principals and teachers

\begin{tabular}{|l|c|c|}
\hline Category participants & Number of population & Samples \\
\hline Senior chiefs & 8 & 8 \\
\hline Principals & 207 & 123 \\
\hline Teachers & 14170 & 405 \\
\hline
\end{tabular}

\subsection{The Normality Test}

The researcher used the Normal test to compare the shape of the study sample distribution to the shape of a normal curve. This test assumes that if the sample is normal shaped then the sample from which it came is normally distributed. A significant test means the sample distribution is not shaped like a normal curve Shapiro Wilks $\mathrm{W}$ test is the one that will used the most. Shapiro Wilks W Test formula.

$$
W=\frac{\left(\sum_{i=1}^{n} a_{i(i)}\right)^{2}}{\left(\sum_{i=1}^{n} X_{(i)}\right)^{2}-X} .
$$

\subsection{Descriptive Analysis}

Computations were made by using the Statistical Package for the Social Sciences SPSS Software package analysis of chi- Square, in order to test the hypothesis of the study. The Alpha was used at 0.05 level of significance in the hypothesis tests. The researcher assumes that there is a statistically significance at level 05 .

The researcher conducted independent $Z$ test that indicate a significant difference $(\mathrm{P}<0.05)$ to determine the level of differences of data variables.

According to Table 2 there are different levels of perception when compared between positions of teachers, principals and school senior chiefs. The Table 2 demonstrates a significant difference between teachers, principals and senior chiefs, $(\mathrm{P}<0.05)$ through the use of chi- Square- K$\mathrm{W}$ in cases of the positions - see Appendix B.

The comparison between the views of three positions was clearly differentiated, the results respectively were, School senior chiefs $54.9 \%$, teachers $75.5 \%$ and principals $84.8 \%$, demonstrating a contrast in the information of participants' perspectives. The Table 2 shows statistically significant difference between participants groups $\mathrm{P}<0.05$ except the job expectancy is not statistically significant difference the significant is 0.127 which is more than $\mathrm{P}$ value. Based on The researcher determines to investigate deeply regarding the contrast between the participants view using focus group with senior chiefs to enrich the data with more information.

Regarding gender factor, Table 3 compares between male and female as shown in the information. The result demonstrates that there is a statistically insignificant difference between male and female $\mathrm{p}>0.05$ in the M.W$\mathrm{Z}$ Test of all cases of gender when related the leadership styles and its. Table 3 shows the mean of female is higher than male in the term of supportive leadership, participative leadership, job satisfaction and job expectancy. See Appendix C.

Table 2. Differences attitudes and perceptions of participants

\begin{tabular}{|c|c|c|c|c|c|c|}
\hline Participants & Directive style & Supportive style & Participative style & Achievement-oriented style & Job Expectancy & Total \\
\hline Teachers & $76.25 \%$ & $76.47 \%$ & $74.50 \%$ & $75.56 \%$ & $76.09 \%$ & $75.5 \%$ \\
\hline Principals & $85.42 \%$ & $87.22 \%$ & $84.45 \%$ & $83.74 \%$ & $83.41 \%$ & $84.8 \%$ \\
\hline Senior Chiefs & $58.61 \%$ & $60.50 \%$ & $55.00 \%$ & $45.00 \%$ & $55.63 \%$ & $54.9 \%$ \\
\hline Chi- Square & 9.547 & 16.032 & 12.824 & 5.069 & 1.864 & \\
\hline Sig. & 0.002 & 0.000 & 0.000 & 0.024 & 0.127 & \\
\hline
\end{tabular}

Table 3. The relation between the gender and variables

\begin{tabular}{|c|c|c|c|c|c|}
\hline Variables & Gender & $\mathrm{N}$ & Mean & z-test & Sig. (2-tailed) \\
\hline Directive Leadership & Female & $\begin{array}{l}214 \\
322\end{array}$ & $\begin{array}{l}3.8775 \\
3.9224\end{array}$ & -1.721 & .085 \\
\hline Supportive leadership & $\begin{array}{c}\text { Female } \\
\text { Male }\end{array}$ & $\begin{array}{l}214 \\
322\end{array}$ & $\begin{array}{l}3.9461 \\
3.9275\end{array}$ & -.869 & .385 \\
\hline $\begin{array}{l}\text { Participative } \\
\text { leadership }\end{array}$ & $\begin{array}{l}\text { Female } \\
\text { Male }\end{array}$ & $\begin{array}{l}214 \\
322\end{array}$ & $\begin{array}{l}3.8624 \\
3.7993 \\
\end{array}$ & -.458 & .647 \\
\hline $\begin{array}{l}\text { Achievement-oriented } \\
\text { leadership }\end{array}$ & $\begin{array}{l}\text { Female } \\
\text { Male }\end{array}$ & $\begin{array}{l}214 \\
322\end{array}$ & $\begin{array}{l}3.8084 \\
3.8758\end{array}$ & -1.376 & .169 \\
\hline Job expectancy & $\begin{array}{l}\text { Female } \\
\text { Male }\end{array}$ & $\begin{array}{l}214 \\
322\end{array}$ & $\begin{array}{l}3.8738 \\
3.8727\end{array}$ & -.791 & .429 \\
\hline
\end{tabular}


Table 4. The relationship between DSPA and teachers job expectancy

\begin{tabular}{|c|c|c|c|c|c|c|c|c|}
\hline \multirow{2}{*}{ Teachers Job expectancy } & \multicolumn{2}{|c|}{ Directive Leadership } & \multicolumn{2}{|c|}{ Supportive leadership } & \multicolumn{2}{|c|}{ Participative leadership } & \multicolumn{2}{|c|}{ Achievement-oriented leadership } \\
\hline & High & low & High & low & High & low & High & Low \\
\hline Job expectancy & 4.393 & 2.871 & 4.443 & 2.860 & 4.336 & 2.742 & 4.394 & 2.695 \\
\hline Z-test & \multicolumn{2}{|c|}{-15.463} & \multicolumn{2}{|c|}{-15.643} & \multicolumn{2}{|c|}{-15.867} & \multicolumn{2}{|c|}{-15.394} \\
\hline Sig. & \multicolumn{2}{|c|}{0.000} & \multicolumn{2}{|c|}{0.000} & \multicolumn{2}{|c|}{0.000} & \multicolumn{2}{|c|}{0.000} \\
\hline
\end{tabular}

In the next turn, Table 4 illustrate the relationship between DSPA and teachers job expectancy JE. The variables were divided into high and low parts based on the Median of the variables of teachers' outcomes. The average of DSPA was then set in each part, the difference between was using $\mathrm{Z}$ test. The table shows $\mathrm{P}$-value less than 0.05 there is statistically significant relation between and leadership styles DSPA and job expectancy. See Appendix D.

\subsection{Testing the Hypothesis}

The null hypotheses were formulated in order to explore the relationship amongst leadership styles, instructional leadership factor and the teachers outcomes. These hypotheses have been mentioned earlier in Chapter 3. They are cited again in this chapter and the data obtained from 536 principals, teachers and school senior chiefs participated in the study were used to test these hypotheses. The Simple Regression analysis is broadly applicable to hypotheses generated by researchers in behavioral sciences, health educational sciences and business sciences. These hypotheses come from formal theory or previous research [12].

\subsubsection{The results of Simple Regression to Test the Hypothesis Effect of DSPA on IL}

Based on the research questions the hypotheses were formulated and were subjected to statistical analysis at 0.05 level of confidence for acceptance or rejections.

Therefore, the researcher tested leadership styles by calculating statistically the DSPA influence on instructional leadership IL forming the relation of Simple Regression; $\mathrm{H} 1, \mathrm{H} 2, \mathrm{H} 3, \mathrm{H} 4$,

The researcher considers leadership styles (DSPA) has an effect on (IL) in an observational analysis. The shape of effective relation between variables based on the Simple Linear Regression formula used to test the effectiveness of (IL).

Testing the relationship between instructional leadership and DSPA show that the size of correlation R between IL is very high more than $90 \%$. For example, Directive leadership is $95.3 \%$ which means that there is appositive relation, illustrate that whenever increase of Directive leadership of $100 \%$ contributed to increases Instructional leadership $95.3 \%$ and so on to other leadership that show a significant relation. According to Adjective $\mathrm{R}^{2}$ the result shows that supportive $95.2 \%$ and participative $95.1 \%$ leadership styles is the higher relation effect on instructional leadership see Appendix E. According to House and Dessler's items, supportive and directive leadership behaviors are usually reported sufficiently higher than the others.
Table 5. Simple Regression analysis for (DSPA) effect on (IL)

\begin{tabular}{|c|c|c|c|c|c|}
\hline Model & $\mathrm{R}$ & $\mathrm{R}^{2}$ & Adj $\mathrm{R}^{2}$ & T. test & Sig. \\
\hline Directive & $.953^{\mathrm{a}}$ & .909 & .909 & 72.970 & 0.000 \\
\hline Supportive & $.976^{\mathrm{a}}$ & .952 & .952 & 102.868 & 0.000 \\
\hline Participative & $.975^{\mathrm{a}}$ & .951 & .951 & 101.990 & 0.000 \\
\hline Achievement- oriented & $.918^{\mathrm{a}}$ & .844 & .843 & 53.652 & 0.000 \\
\hline
\end{tabular}

Moreover, the contribution from this results of Table 5 supports the researcher's assumption; that there is a significant and effective relationship between instructional leadership and leadership styles that enhance to principal roles as leader. $\mathrm{R}^{2}$ illustrate the size effect of DSPA on IL according show a highly effect more than $90 \%$ while achievement -oriented leaders has the less impact 84.4\% but still high. The Regression information of each item with the total score on items found. The analysis of the data results that the tested hypothesis of each leadership style effect on (IL);

According to $\mathrm{H} 1, \mathrm{H} 2, \mathrm{H} 3, \mathrm{H} 4$ There is a positive and a significant impact $(0.000)$ of leadership style directive, supportive, participative, achievement-oriented on instructional leadership. Therefore, the relation $\mathrm{P}<0.05$

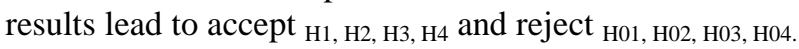

\subsubsection{The Results of Simple Regression to Test the Hypothesis Effect of DSPA on the Relation between IL and JE}

The shape of effective relation between variables based on the Simple Linear Regression formula used to test the effectiveness of DSPA on the relationship of IL on job satisfaction (JS); $\mathrm{H}_{5}, \mathrm{H} 6, \mathrm{H} 7, \mathrm{H} 8$,

According to Table 6 the results support the research assumption of the existence of relationships between instructional leadership and job expectancies when related to DSPA. The information in Table 6 represents a simple regression analysis conducted to evaluate the attributes of (IL) on (JE).

Table 6 is about testing DSPA on the relationship between instructional leadership and job expectancies. The table starts to shows the IL effect on job expectancies JE then compare the impact on this relation when related to each one of leadership styles DSPA. The size of effect of $\mathrm{R}^{2}$ shows $80.4 \%$ between IL and JE this rate become to increase when related to leadership styles, the size of effect $\mathrm{R}^{2}$ of directive leadership on the relationship between IL and JE increased to $83.1 \%$, the size of effect $\mathrm{R}^{2}$ of supportive leadership on the relationship between IL and JE increased to $83.4 \%$, the size of effect $\mathrm{R}^{2}$ of participative leadership on the relationship between IL and JE increased to $82.5 \%$. and the size of effect $\mathrm{R}^{2}$ of achievement- oriented leadership on the relationship between IL and JE increased to 80.9\%. The analysis 
shows a strong significant 0.000 and the regression equation was statistically significant $\mathrm{P}<0.05$. The simple regression analysis shows the strength DSPA on the relationship between Instructional leadership (IL) job satisfaction (JE). See Appendix F.

\subsection{Data Collected through a Focus Group Interview}

The main reason for the focus group interviews was the inconsistency of the senior chiefs opinions when compared to the principals and teachers opinions after analyzing the questionnaires in accordance with the quantitative approach. The proportion of senior chiefs satisfaction was less and hence prompted the researcher to use a qualitative approach. A focus group was conducted and the transcription of the interview is kept as provided and summarized in a Table 7. An analysis of the interview between the researcher (Moderator or Interviewer) and eight senior chiefs show in table below.

This study aims to contribute to the knowledge by identifying relations and comparing between certain types of leaderships in the field of education. The study concludes that instructional leadership is strengthened when associated with other types of leaderships manifested by reducing management practices and enhancing leadership characteristics.

This study found that instructional leadership has the ability to promote school leadership and reforms embedding leadership styles in the role of a school principal, such an approach provides better impact on teachers' job expectancy.

The theoretical contribution of this study focuses on Path Goal Theory which contributes to transform instructional leadership into a form that can enhance the leadership role.
According to focus group result. The study found that to reduce the principal's managerial work requires considering the effective distributive leadership concept among assistant principal and senior teachers supervisor based on collaborative, collective and coordinative distribution. Distributed leadership is a result of reflecting the organizational management regarding the view that leadership roles and positions should be shared, distributed leadership addresses the entirety of human resources in organizations, especially the academic staff in educational organizations as leader. School management, which is a complicated and hard task, cannot be left to a single leader or leadership approach or potential because school structures are not easy to be managed effectively with the leadership of a single person [18]. In addition, distributive leadership concept also supports the school counselors' role in solving students' disciplinary issues. School counselors must become a critical partner in a leadership team Uhl-Bien, Maslyn, \&Ospina [61].

The study found relationship between job expectancy and transitional leadership the result confirm that justice rewarding requires estimating job expectancy that leads to raise in the level of performances. Therefore, Transactional Leadership is the most sufficient method to reward performances. A study by Shah [52] results that transactional leadership has positive relationship with job performance. Transactional leadership style subordinators are motivated only if they get many and promotion [16]. According to Memduhoglu \& Yildiz [41] in order to enable teachers in school to work with more energy, teachers need to believe the procedural justice concerns fair tend and strict to perceive the distribution of awards and punishments fairly.

The study found that job expectancy influence more with achievement- rather than directive or supportive or participative leadership styles.

Table 6. Simple Regression Analysis for instructional leadership (IL) as Predictor of (JE)

\begin{tabular}{|l|c|c|c|c|c|}
\hline \multirow{2}{*}{ Model } & \multicolumn{5}{|c|}{ Model Summary } \\
\cline { 2 - 6 } & $\mathrm{R}$ & R Square & Adjusted Square & T-test & Sig. \\
\hline IL effects on JE & $.897^{\mathrm{a}}$ & .804 & .804 & 46.850 & .000 \\
\hline (IL * Directive ) effect on JE $^{2}$ & $.912^{\mathrm{a}}$ & .831 & .831 & 51.259 & .000 \\
\hline (IL * Supportive e ) effect on JE & $.913^{\mathrm{a}}$ & .834 & .834 & 51.844 & .000 \\
\hline (IL * participative) effect on JE $^{2}$ & $.908^{\mathrm{a}}$ & .825 & .825 & 50.147 & .000 \\
\hline (IL * Achievement-oriented) effect on JE & $.900^{\mathrm{a}}$ & .809 & .809 & 47.583 & .000 \\
\hline
\end{tabular}

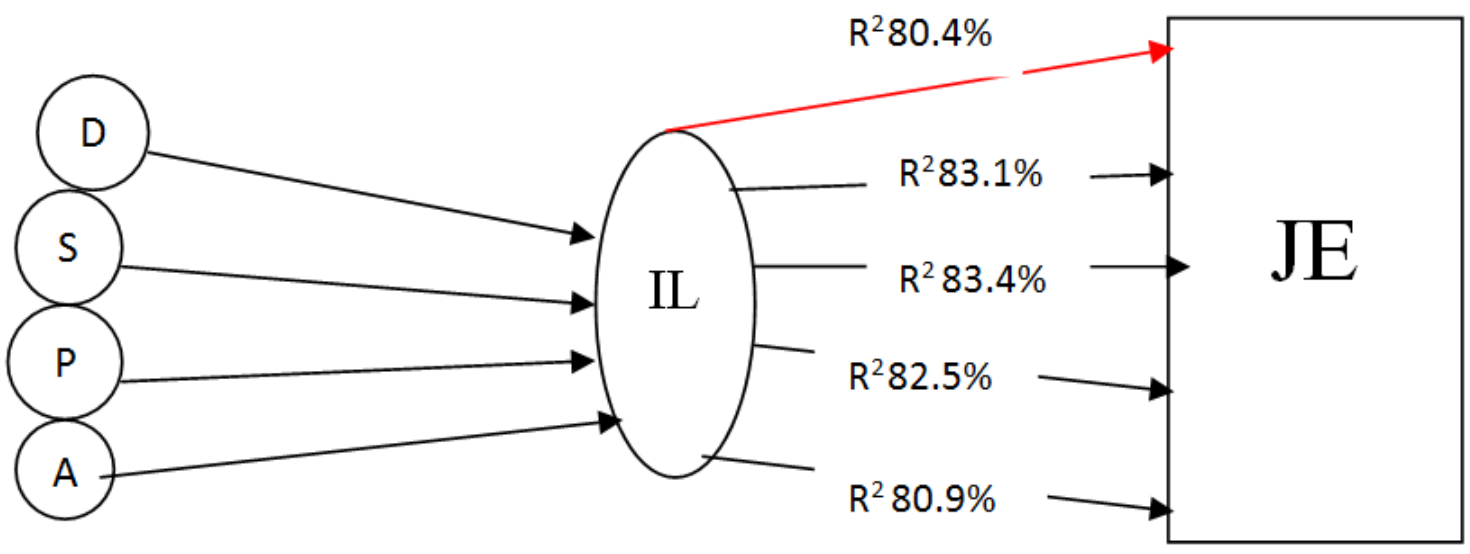

Figure 4. The measure of the effect of the leadership style DSPA on the relationship between IL and JE 
Table 7. Senior chiefs focus group responds

\begin{tabular}{|c|c|c|c|c|c|c|}
\hline \multirow[b]{2}{*}{ Question 1} & \multirow[b]{2}{*}{ Participants } & \multirow[b]{2}{*}{ Gender } & \multicolumn{4}{|l|}{ Senior chiefs focus group responds } \\
\hline & & & $\begin{array}{l}\text { Directive } \\
\text { Leadership style }\end{array}$ & $\begin{array}{l}\text { Supportive } \\
\text { Leadership style }\end{array}$ & $\begin{array}{l}\text { Participative } \\
\text { Leadership style }\end{array}$ & $\begin{array}{l}\text { Achievement - } \\
\text { oriented } \\
\text { Leadership style }\end{array}$ \\
\hline \multirow{3}{*}{$\begin{array}{l}\text { To what extent } \\
\text { does the four } \\
\text { leadership styles } \\
\text { DSPA affect the } \\
\text { instructional } \\
\text { leadership } \\
\text { approach? }\end{array}$} & R1 & Male & $\begin{array}{l}\text { Very important, and must } \\
\text { strengthen the role for guiding } \\
\text { teachers. } \\
\text { In order to direct teachers there } \\
\text { must be a cooperative monitoring } \\
\text { between principal, supervisor, } \\
\text { assistant principal and senior } \\
\text { teachers. }\end{array}$ & $\begin{array}{l}\text { Supportive factor is } \\
\text { necessary for teachers. } \\
\text { A Principal is in need } \\
\text { of being more } \\
\text { initiative in this field, } \\
\text { care about the school } \\
\text { surrounding } \\
\text { environment in terms } \\
\text { of substantive rather } \\
\text { than aesthetic. }\end{array}$ & $\begin{array}{l}\text { participative is a } \\
\text { critical factor in } \\
\text { building a } \\
\text { constructive } \\
\text { relationship }\end{array}$ & $\begin{array}{l}\text { Very important } \\
\text { for school quality } \\
\text { outcome }\end{array}$ \\
\hline & R2 & Female & $\begin{array}{l}\text { Exists in school leaders but needs } \\
\text { to be rooted in principals } \\
\text { behavior. Some school principals } \\
\text { do apply directive leadership } \\
\text { style. }\end{array}$ & $\begin{array}{l}\text { Exist in the school } \\
\text { environment and } \\
\text { evident in the clear } \\
\text { interest of meeting the } \\
\text { physical and service } \\
\text { needs of teachers. }\end{array}$ & $\begin{array}{l}\text { The concept of } \\
\text { participative style } \\
\text { or sharing based } \\
\text { on a group of } \\
\text { participant is } \\
\text { essential. All } \\
\text { members in school } \\
\text { should be leaders. }\end{array}$ & $\begin{array}{l}\text { Exists in school } \\
\text { leaders but needs } \\
\text { to be rooted in } \\
\text { principals } \\
\text { behavior. }\end{array}$ \\
\hline & R3 & Male & $\begin{array}{l}\text { Principal does not present an } \\
\text { exemplary character in } \\
\text { committing to these leadership } \\
\text { styles. } \\
\text { It is important to share the } \\
\text { supervision process in order to } \\
\text { guide. }\end{array}$ & $\begin{array}{l}\text { Does not present } \\
\text { exemplary } \\
\text { characteristic in } \\
\text { Principals' behavior }\end{array}$ & $\begin{array}{l}\text { participative } \\
\text { leadership style } \\
\text { particularly does } \\
\text { not present } \\
\text { exemplary } \\
\text { characteristic in } \\
\text { Principals' } \\
\text { behavior } \\
\end{array}$ & $\begin{array}{l}\text { Does not present } \\
\text { exemplary } \\
\text { characteristic in } \\
\text { Principals' } \\
\text { behavior }\end{array}$ \\
\hline & R4 & Female & $\begin{array}{l}\text { guidance is given to teachers in } \\
\text { general but female principals } \\
\text { have shown more concern than } \\
\text { males regarding this style. }\end{array}$ & $\begin{array}{l}\text { There is a supportive } \\
\text { environment for } \\
\text { teachers' need } \\
\text { particularly in using } \\
\text { the technology. }\end{array}$ & $\begin{array}{l}\text { participative } \\
\text { leadership is } \\
\text { missing in schools } \\
\text { in general. }\end{array}$ & - \\
\hline & R5 & Female & $\begin{array}{l}\text { Very important and } \\
\text { plays a prominent role in schools. } \\
\text { Principals need to take this type } \\
\text { of leadership style into } \\
\text { consideration especially towards } \\
\text { new teachers. }\end{array}$ & $\begin{array}{l}\text { Supportive behavior } \\
\text { takes place in } \\
\text { activating the school } \\
\text { environment but does } \\
\text { not have a noticeable } \\
\text { impact on the level of } \\
\text { students achievement } \\
\text { and or teacher's } \\
\text { satisfaction }\end{array}$ & $\begin{array}{l}\text { Need to encourage } \\
\text { the participating } \\
\text { behavior }\end{array}$ & - \\
\hline & R6 & Female & $\begin{array}{l}\text { Very important and needed. } \\
\text { Directive style has to be a } \\
\text { continuous process from various } \\
\text { resources. }\end{array}$ & $\begin{array}{l}\text { Very important and } \\
\text { needed }\end{array}$ & $\begin{array}{l}\text { Very important } \\
\text { and needed, in } \\
\text { addition to the } \\
\text { idea that } \\
\text { participants } \\
\text { leadership needs } \\
\text { all parties internal } \\
\text { or external to take } \\
\text { their } \\
\text { responsibility. }\end{array}$ & $\begin{array}{l}\text { Very important } \\
\text { and needed. }\end{array}$ \\
\hline & R7 & Male & $\begin{array}{l}\text { Necessary and essential specially } \\
\text { for new teachers. }\end{array}$ & $\begin{array}{l}\text { Important and } \\
\text { necessary. Most } \\
\text { school give attention } \\
\text { to the environment } \\
\text { and utilize the } \\
\text { resource to staff }\end{array}$ & $\begin{array}{l}\text { Important and } \\
\text { necessary }\end{array}$ & $\begin{array}{l}\text { Achievement- } \\
\text { oriented } \\
\text { leadership style is } \\
\text { the most } \\
\text { challenging } \\
\text { amongst these } \\
\text { leadership styles } \\
\text { because may be } \\
\text { able to } \\
\text { distinguish the } \\
\text { active role of an } \\
\text { instructional } \\
\text { leader. }\end{array}$ \\
\hline & R8 & Female & $\begin{array}{l}\text { Most effective when managers } \\
\text { focus on preparing school leaders }\end{array}$ & $\begin{array}{l}\text { Teachers do not get } \\
\text { enough support from } \\
\text { training programs yet } \\
\text { principals are not the } \\
\text { ones responsible for } \\
\text { organizing the } \\
\text { professional programs. }\end{array}$ & $\begin{array}{l}\text { Appropriate to an } \\
\text { extent, not entirely } \\
\text { effective }\end{array}$ & $\begin{array}{l}\text { School principal } \\
\text { place high goals } \\
\text { in strategic plans } \\
\text { but for many } \\
\text { factors do not } \\
\text { achieve these } \\
\text { goals in a proper } \\
\text { manner. }\end{array}$ \\
\hline
\end{tabular}




\begin{tabular}{|c|c|c|c|}
\hline Research Questions2 & Participants & Gender & Job expectancy \\
\hline \multirow{8}{*}{$\begin{array}{l}\text { How does the instructional leadership } \\
\text { approach affect job expectancy when } \\
\text { related to the four leadership } \\
\text { styles "directive, supportive, participative } \\
\text { and achievement - oriented effective"? }\end{array}$} & $\mathrm{R} 1$ & Male & $\begin{array}{l}\text { Teachers enhance their performance when they receive a supportive } \\
\text { behavior from the principal and as a result, an increase in job } \\
\text { expectancy. }\end{array}$ \\
\hline & R2 & Female & $\begin{array}{l}\text { Principals adopting DSPA leadership styles affect teachers motivation } \\
\text { and satisfaction positively, hence motivation towards achievement. }\end{array}$ \\
\hline & R3 & Male & $\begin{array}{l}\text { The principal who practice achievement- oriented -style, reward } \\
\text { teachers who do great performance because they are concerned about } \\
\text { achieving high goal. }\end{array}$ \\
\hline & R4 & Female & $\begin{array}{l}\text { Apply justice in rewarding and encouraging teachers morally will create } \\
\text { a positive climate. A principal has to be strict in rewarding, an aspect } \\
\text { also known as a transactional leadership; in order to be rewarded there } \\
\text { is a task to be fulfilled. }\end{array}$ \\
\hline & R5 & Female & $\begin{array}{l}\text { Teacher's job expectation will increase if school principals commit to } \\
\text { the criteria of the four leadership styles. } \\
\text { T here is an understanding between principal and teachers regarding the } \\
\text { rewarding approach. }\end{array}$ \\
\hline & R6 & Female & $\begin{array}{l}\text { Achievement- oriented is the proper style for principals to reward } \\
\text { teachers based on their extreme effort. Rewarding should be strict and } \\
\text { given based on worthiness. } \\
\text { Participative leadership is the most effective in enhancing teacher's } \\
\text { satisfaction. }\end{array}$ \\
\hline & R7 & Male & $\begin{array}{l}\text { Rewarding should be given based on worthiness, otherwise teachers } \\
\text { might subject to accountability and punishment. }\end{array}$ \\
\hline & R8 & Female & $\begin{array}{l}\text { We need to change the culture of rewarding, to establish a new } \\
\text { understanding that rewarding is not based on personal relations, } \\
\text { personalities or emotions to increase teachers satisfaction, }\end{array}$ \\
\hline Research Questions2 & Participants & Gender & Job expectancy \\
\hline \multirow{8}{*}{$\begin{array}{l}\text { How does the instructional leadership } \\
\text { approach affect job expectancy when } \\
\text { related to the four leadership } \\
\text { styles "directive, supportive, participative } \\
\text { and achievement - oriented effective"? }\end{array}$} & R1 & Male & $\begin{array}{l}\text { Teachers enhance their performance when they receive a supportive } \\
\text { behavior from the principal and as a result, an increase in job } \\
\text { expectancy. }\end{array}$ \\
\hline & R2 & Female & $\begin{array}{l}\text { Principals adopting DSPA leadership styles affect teachers motivation } \\
\text { and satisfaction positively, hence motivation towards achievement. }\end{array}$ \\
\hline & R3 & Male & $\begin{array}{l}\text { The principal who practice achievement- oriented -style, reward } \\
\text { teachers who do great performance because they are concerned about } \\
\text { achieving high goal. }\end{array}$ \\
\hline & $\mathrm{R} 4$ & Female & $\begin{array}{l}\text { Apply justice in rewarding and encouraging teachers morally will create } \\
\text { a positive climate. A principal has to be strict in rewarding, an aspect } \\
\text { also known as a transactional leadership; in order to be rewarded there } \\
\text { is a task to be fulfilled. }\end{array}$ \\
\hline & R5 & Female & $\begin{array}{l}\text { Teacher's job expectation will increase if school principals commit to } \\
\text { the criteria of the four leadership styles. } \\
\text { T here is an understanding between principal and teachers regarding the } \\
\text { rewarding approach. }\end{array}$ \\
\hline & R6 & Female & $\begin{array}{l}\text { Achievement- oriented is the proper style for principals to reward } \\
\text { teachers based on their extreme effort. Rewarding should be strict and } \\
\text { given based on worthiness. } \\
\text { Participative leadership is the most effective in enhancing teacher's } \\
\text { satisfaction. }\end{array}$ \\
\hline & R7 & Male & $\begin{array}{l}\text { Rewarding should be given based on worthiness, otherwise teachers } \\
\text { might subject to accountability and punishment. }\end{array}$ \\
\hline & R8 & Female & $\begin{array}{l}\text { We need to change the culture of rewarding, to establish a new } \\
\text { understanding that rewarding is not based on personal relations, } \\
\text { personalities or emotions to increase teachers satisfaction, }\end{array}$ \\
\hline
\end{tabular}

\section{Conclusion}

This study statistically insignificant differences between the male and female on applying instructional leadership when related to DSPA. According to Murdoch (2013) support this result that there is no statistically significant differences between male and female leadership styles and subordinates' commitment to their superior. This may be due to the fact that there is no discrimination between male and female, both genders have similar background knowledge, theoretical cognitive and are receiving apprenticeship programs-sum without bias for preparing school leader.

While regarding to this study, senior chief's viewed that differences females play the role of instructional leader batter than male. However, another study by Ayman \&
Korabik [2] shows that women possess more participative leadership styles than their male counterparts. While a study by Celikten [11]; Gumus\& Akcaoglu [20] indicates that gender plays an important role in affecting teachers' perceptions; teachers rate their female principals' instructional leadership skills lower than male principals.

The study found that directive leadership style is the most proper for new teachers in particular to be in need of specific guidance provided, schedules, rules, regulations and standards in the beginning of their career as well as to know what is exactly expected from them. According to Stinson and Johnson [55] found that directive leadership is effective with subordinates who have lower levels of education and weaker needs for achievement and independence.

The study conclude that principals in kingdom of Bahrain must be aware and know about the new facts of the role principal as instructional leader and not lay on their personal experience. Additionally, the findings can 
help decision makers construct and formulate robust decisions suitable for professional development programmes that prepares principals to gain skills, knowledge and promote their experience.

\section{References}

[1] Alig-Mielcarek, Jana Michelle. (2003). A model of school success: Instructional leadership, academic press, and student achievement. Diss. The Ohio State University, 2003.

[2] Ayman R. \&Korabik K. (2010). Leadership: why gender and culture matter. American Psychologist 65 (3), 157-170.

[3] Barnes, C. A., Camburn, E., Sanders, B. R., \& Sebastian, J. (2010). Developing instructional leaders: Using mixed methods to explore the black box of planned change in principals' professional practice. Educational Administration Quarterly, 46(2), 241-279.

[4] Blankstein, A. M. (2010). Failure is not an option: 6 principles for making student success the only option (2nd ed.). Thousand Oaks, CA: Sage.

[5] Blase, J., \& Blasé J. (2000). Effective instructional leadership: Teachers' perspectives on how principals promote teaching and learning in schools. Journal of Educational Administration, 38, 130-141.

[6] Bogdan, R. C. \& Biklen, K. S. (2003). Qualitative Research for Education. An Introduction to Theory and Methods. Boston: Allyn and Bacon.

[7] Boyle-Baise, M., \& Washburn, J. (1995). Coalescing for Change: The Coalition for Education That Is Multicultural. Journal of Teacher Education, 46(5), 351-59.

[8] Bryman, A. and Bell, E. (2007). Business research methods. Oxford University Press, USA.

[9] Buyukozturk S, Akbaba-Altun S and Yildirim K (2010). Teaching and Learning International Survey: National Report for Turkey. Ankara: MEB.

[10] Calik, T., Sezgin, F., Kavgaci, H., \& Kilinc, A. (2012). Examination of relationships between instructional leadership of school principals and self-efficacy of teachers and collective teacher efficacy. Educational Sciences: Theory and Practice, 12(4), 2498-2504.

[11] Celikten M (2005). A perspective on women principals in Turkey. International Journal of Leadership in Education 8(3): 207-221.

[12] Cohen, J., Cohen, P., West, S. G., \& Aiken, L. S. (2013). Applied multiple regression/correlation analysis for the behavioral sciences. Routledge.

[13] Colvin, R. L. (2010). A 10-year climb: Education leadership reaches the national reform agenda. Copyright $($ 2010 The Wallace Foundation, 6.

[14] Creswell, J. W. (2005). Educational research: Planning, conducting, and evaluating quantitative and qualitative research. Upper Saddle River, New Jersey: Pearson Education, Inc.

[15] Ezzat, H., Agogué, M., Le Masson, P., \& Weil, B. (2017). Solution-oriented versus Novelty-oriented Leadership Instructions: Cognitive Effect on Creative Ideation. In Design Computing and Cognition'16 (pp. 99-114). Springer, Cham.

[16] Girma, S. (2016). The relationship between leadership style and employee job satisfaction study of federal and Addis Ababa sport organizational management setting in Ethiopia. IJAR, 2(3), 92-96.

[17] Goddard, R., Goddard, Y., Sook Kim, E., \& Miller, R. (2015). A theoretical and empirical analysis of the roles of instructional leadership, teacher collaboration, and collective efficacy beliefs in support of student learning. American Journal of Education, 121(4), 501-530.

[18] Göksoy, S. (2015). Distributed Leadership in Educational Institutions. Journal of Education and Training Studies, 3(4), 110-118.

[19] Goldring, E., Cravens, X., Porter, A., Murphy, J., \& Elliott, S. (2015). The convergent and divergent validity of the Vanderbilt Assessment of Leadership in Education (VAL-ED) Instructional leadership and emotional intelligence. Journal of Educational Administration, 53(2), 177-196.

[20] Gumus, S., \&Akcaoglu, M. (2013). Instructional Leadership in Turkish Primary Schools An Analysis of Teachers' Perceptions and Current Policy. Educational Management Administration \& Leadership, 41(3), 289-302.
[21] Hallinger, P., \& Wang, W. C. (2015). Assessing instructional leadership with the Principal Instructional Management Rating Scale. Dordrecht, Netherlands: Springer.

[22] Hallinger, P., \& Lee, M. S. (2013). Exploring principal capacity to lead reform of teaching and learning quality in Thailand. International Journal of Educational Development, 33, 305-315.

[23] Hallinger, P. (2005). Instructional leadership and the school principal: A passing fancy that refuses to fade away. Leadership and Policy in Schools, 4, 221-239.

[24] Hallinger, P \& Murphy, J. (1985). Assessing the instructional management behaviors of principals. The Elementary School Journal, 86, (2), 217-247.

[25] Hattie, J. A.C. (2009). Visible learning: A synthesis of over 800 meta-analyses relating to achievement. New York, NY: Routledge.

[26] Heck, R. H \& Hallinger, P. (2014). Modeling the longitudinal effects of school leadership on teaching and learning. Journal of Education Administration, 52, 653-681.

[27] Hoberg, S.A. 1999. Education management: research methodology. Pretoria: University of South Africa.

[28] House, R. J., \&Dessler, G. (1974). The path-goal theory of leadership: Some post hoc and a priori tests. In. J. G. Hunt \& L. L. Larson (Eds.), Contingency Approaches to Leadership. Carbondale, IL: Southern Illinois University Press.

[29] House, R, J., and Mitchell, T. R. (1974). Path-Goal Theory of Leadership. Contemporary Business, 3, 81-98.

[30] Knight, A. P., Shteynberg, G., \&Hanges, P. J. (2011) Path-Goal Analysis. Goethals, Sorenson, and Burns, 3, 1164-69.

[31] Lashway, L. (2002). Developing Instructional Leaders. (ERIC U.S Department of Education contract No.ED-99-C0-0011).

[32] Lambert, L. (2002). The constructivist leader. Teachers College Press.

[33] Lawler, E., \& Suttle, J. (1973). Expectancy theory and job behavior. Organizational Behavior And Human Performance, 9(3), 482-503.

[34] Leithwood, K., Louis, K. S., Anderson, S., \&Wahlstrom, K. (2004). How leadership influences student learning. University of Minnesota: Center for Applied Research and Educational Improvement, and University of Toronto: Ontario Institute for Studies in Education.

[35] Linda Bendikson, Vivian Robinson \& John Hatttie, (2012). Principal instructional leadership and secondary school performance, TEAC H I N G A N D LEARNING. set 1, 2012. o. 4 pp. 477-89.

[36] Louis, K. S., Leithwood, K., Wahlstrom, K., \& Anderson (2010). Investigating the links to improved student learning: Final report of research findings. Retrieved from Wallace Foundation website: www.wallacefoundation.org/knowledgecenter/schoolleadership/keyresearch/Documents/Investigating-theLinks-to- Improved-Student-Learning.pdf.

[37] Lussier, R. N., and Achua, C. F. (2010). Leadership, Fourth Edition, South-Western Cengage Learning: Mason, USA.

[38] National Policy Board for Educational Administration. (2002). Standards for advanced programs in educational leadership. http://www.npbea.org/ELCC/ELCCStandards\%20_5-02.pdf.

[39] Marks, H. M., \& Printy, S. M. (2003). Principal leadership and school performance: Anintegration of transformational and instructional leadership. Educational Administration Quarterly, 39(3), 370-397.

[40] Marsh, J., Kerr, K., Schuyler-Ikemoto, G., Darilek, H., Suttorp, M., \& Zimmer, R. (2005). The role of districts in fostering instructional improvement: Lessons from three urban districts partnered with the Institute for Learning. Santa Monica, CA: RAND Education.

[41] Memduhoglu, h. b., \& Yildiz, a. ý. (2016). Developing the organisational justice scale and examining teachers' and school administrators 'views about organisational justice in primary schools. mier journal of educational studies, trends and practices, $4(1)$.

[42] Murphy, J. (1988). Methodological, measurement, and conceptual problems in the study of instructional leadership. Educational Evaluation and Policy Analysis, 10(2), 117-139.

[43] Northouse, P. G. (2013). Leadership: Theory and Practice, (6th ed). Sage Publications, Inc.

[44] OECD. (2009) Creating effective teaching and learning environments: first results from TALIS. 
http://www.oecd.org/document/54/0,3343,en_2649_39263231_42 98*.

[45] Polston-Murdoch, L. (2013). An Investigation of path-goal theory, relationship of leadership style, supervisor-related commitment, and gender. Emerging leadership journeys. Virginia: School of Business \& Leadership, 13-44.

[46] Purkey, S. \& Smith, M. (1983). Effective schools: A review. The Elementary School Journal, 83 (4), 427-452.

[47] R. Nisa, (2003). "A study of relationship among college principals and their subordinates job satisfaction and acceptance of leader- A Path-Goal approach,” Unpublished doctoral dissertation, Lahore: The University of Punjab.

[48] Ricard, L. M., Klijn, E. H., Lewis, J. M., \& Ysa, T. (2017). Assessing public leadership styles for innovation: A comparison of Copenhagen, Rotterdam and Barcelona. Public Management Review, 19(2), 134-156.

[49] Richard, D. (2012). Organization theory and design. Cengage learning.

[50] Rigby, J. G. (2014). Three logics of instructional leadership. Educational Administration Quarterly, 50(4), 610-644.

[51] Sekaran, U. (2006). Research methods for business: A skill building approach. John Wiley \& Sons.

[52] Shah, S. M. M., Hamid, A., \& Bin, K. (2015). Transactional Leadership and Job Performance: An Empirical Investigation. Sukkur IBA Journal of Management and Business, 2(2), 69-81.

[53] Situmorang, B. (2014). The effect of instructional leadership, Knowledge of Education of education management, international communication and job satisfaction on organization commitmen of the senior high school principals (A Case Study In Senior High School In Medan Municipality). The Effect Of Instructional Leadership, Knowledge Of Educational Management, Interpersonal Communication And Job Satisfaction On Organization Commitment Ofthe Senoir High School Principals (A Case Study In Senior High School In Medan Municipality)
[54] Southworth, G. (2009). Learning-centered leadership. In B. Davies (Ed.), The essentials of school leadership (pp. 91-111). London: SAGE.

[55] Stinson, J.E. \& Johnson, T. W. (1975). The path-goal theory of leadership: A partial test and suggested refinement. Academy of Management Journal. 18: 242-252.

[56] Stein, L. (2016). Schools Need Leaders-Not Managers: It's Time for a Paradigm Shift. Journal of Leadership Education, 15(2).

[57] Stronge, J. H., Richard, H. B \& Catano, N. (2008). Qualities of Effective Principals. Alexandria, VA: ASCD.

[58] Supovitz, J., Sirinides, P., \& May, H. (2010). How principals and peers influence teaching and learning. Educational Administration Quarterly, 46(1), 31-56.

[59] Townsend, T. (Ed.). (2002). Restructuring and quality: issues for tomorrow's schools. Routledge.

[60] Vecchio, R. P., Justin, J. E., \& Pearce, C. L. (2008). The utility of transactional and transformational leadership for predicting performance and satisfaction within a path-goal theory framework. Journal of Occupational and Organizational Psychology, 81(1), 71-82.

[61] Uhl-Bien, M., Maslyn, J., \& Ospina, S. (2012). The nature of relational leadership: A multi theoretical lens on leadership relationships and process. In D. V. Day \& J. Antonakia (Eds.), The nature of leadership (2nd ed., pp. 289-3300). Thousand Oaks, CA: SAGE. Van Manen, M. (1990). Researching lived experience: Human science for an.

[62] Waters, T., Marzano, R. J., \& McNulty, B. (2003). Balanced leadership: What 30 years of research tells us about the effect of leadership on student achievement. A working paper. Aurora, CO: Mid-Continent Research for Education and Learning. (ERIC Document Reproduction Service No. ED481972).

[63] Yin, R. (1989). Case study research: Design and method. Newbury Park: Sage.

\section{Appendix A: Number of public schools and teachers by sex for the academic year 2014-2015}

Kingdom of Bahrain

The Ministry of Education

Educational Statistics Department

Educational Statistics Section

Number of public schools and teachers by sex for the academic year

2014-2015

\begin{tabular}{|c|c|c|}
\hline Sex & Schools & Teachers \\
\hline Boys schools & 105 & 6966 \\
\hline Girls schools & 102 & 7204 \\
\hline Total & 207 & 14170 \\
\hline
\end{tabular}

Include 1476 Female teacher in boys' schools.

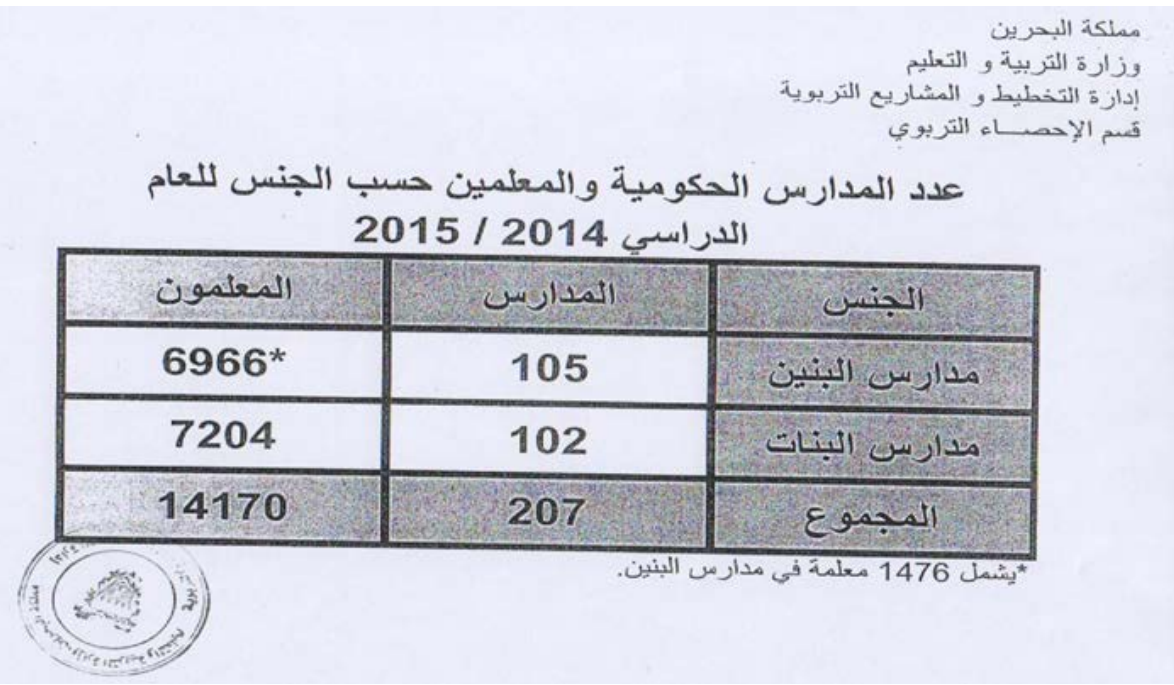




\section{Appendix B: Differences between participants attitude and perception Chi-Square}

Oneway

Test Statistics $\mathbf{a}, \mathbf{b}$
\begin{tabular}{|l|c|c|c|c|c|}
\hline & D & S & P & A & JE \\
\hline Chi-Square & 9.547 & 16.032 & 12.824 & 5.069 & 1.864 \\
df & 1 & 1 & 1 & 1 & 1 \\
Asymp. Sig. & .002 & .000 & .000 & .024 & .172 \\
\hline
\end{tabular}

a. Kruskal Wallis Test

b. Grouping Variable: Job

\section{Appendix C: The relationship between Gender and Variables}

NPar Tests

Mann-Whitney Test

Test Statistics ${ }^{\mathrm{a}}$

\begin{tabular}{|l|c|c|c|c|c|}
\hline & D & S & P & A & JE \\
\hline Mann-Whitney U & 31437.000 & 32928.500 & 33651.000 & 32094.500 & 33077.000 \\
Wilcoxon W & 54442.000 & 55933.500 & 85654.000 & 55099.500 & 56082.000 \\
Z & -1.721 & -.869 & -.458 & -1.376 & -.791 \\
Asymp. Sig. (2-tailed) & .085 & .385 & .647 & .169 & .429 \\
\hline
\end{tabular}

a. Grouping Variable: Sex

\section{Appendix D: The relationship between leadership styles DSPA and job Expectancy}

DSPA on JE

NPar Tests

Group Statistics

\begin{tabular}{|c|c|c|c|c|c|}
\hline & JE $>=4$ (FILTER) & $\mathrm{N}$ & Mean & Std. Deviation & Std. Error Mean \\
\hline \multirow{2}{*}{$\mathrm{D}$} & Selected & 364 & 4.3926 & .47616 & .02496 \\
& Not Selected & 172 & 2.8714 & 1.00697 & .07678 \\
\hline \multirow{2}{*}{$\mathrm{S}$} & Selected & 364 & 4.4430 & .46808 & .02453 \\
& Not Selected & 172 & 2.8597 & 1.00517 & .07664 \\
\hline \multirow{2}{*}{$\mathrm{P}$} & Selected & 364 & 4.3362 & .49667 & .02603 \\
& Not Selected & 172 & 2.7415 & .97419 & .07428 \\
\hline \multirow{2}{*}{$\mathrm{A}$} & Selected & 364 & 4.3942 & .59770 & .03133 \\
& Not Selected & 172 & 2.6948 & 1.06575 & .08126 \\
\hline
\end{tabular}

\section{Mann-Whitney Test}

Test Statistics ${ }^{\mathbf{a}}$
\begin{tabular}{|l|c|c|c|c|}
\hline & D & S & P & A \\
\hline Mann-Whitney U & 5467.000 & 5142.000 & 4775.500 & 6135.500 \\
Wilcoxon W & 20345.000 & 20020.000 & 19653.500 & 21013.500 \\
Z & -15.463 & -15.643 & -15.867 & -15.394 \\
Asymp. Sig. (2-tailed) & .000 & .000 & .000 & .000 \\
\hline
\end{tabular}

a. Grouping Variable: JE >= 4 (FILTER)

\section{Appendix E: Simple regression of the relationship between leadership styles and instructional leadership.}

1. Simple regression of the relationship between Directive leadership style and instructional leadership.

Model Summary
\begin{tabular}{|l|c|c|c|c|}
\hline Model & R & R Square & Adjusted R Square & Std. Error of the Estimate \\
\hline 1 & $.953^{\mathrm{a}}$ & .909 & .909 & .29677 \\
\hline
\end{tabular}




ANOVA $^{\mathrm{a}}$ :
\begin{tabular}{|ll|c|c|c|c|c|}
\hline Model & Sum of Squares & $\mathrm{df}$ & Mean Square & F & Sig. \\
\hline & Regression & 468.956 & 1 & 468.956 & 5324.636 & $.000^{\mathrm{b}}$ \\
& Residual & 47.031 & 534 & .088 & & \\
& Total & 515.987 & 535 & & & \\
\end{tabular}

a. Dependent Variable: IL

b. Predictors: (Constant), D

Coefficientsa

\begin{tabular}{|c|c|c|c|c|c|c|}
\hline \multirow{2}{*}{\multicolumn{2}{|c|}{ Model }} & \multicolumn{2}{|c|}{ Unstandardized Coefficients } & \multirow{2}{*}{$\begin{array}{c}\text { Standardized Coefficients } \\
\text { Beta }\end{array}$} & \multirow[b]{2}{*}{$\mathrm{t}$} & \multirow[b]{2}{*}{ Sig. } \\
\hline & & B & Std. Error & & & \\
\hline \multirow{2}{*}{1} & (Constant) & .176 & .052 & & 3.372 & .001 \\
\hline & $\mathrm{D}$ & .944 & .013 & .953 & 72.970 & .000 \\
\hline
\end{tabular}

a. Dependent Variable: IL

2. Simple regression of the relationship between Supportive leadership style and instructional leadership.

Coefficients $^{\mathrm{a}}$

\begin{tabular}{|c|c|c|c|c|c|c|}
\hline \multirow{2}{*}{\multicolumn{2}{|c|}{ Model }} & \multicolumn{2}{|c|}{ Unstandardized Coefficients } & \multirow{2}{*}{$\frac{\text { Standardized Coefficients }}{\text { Beta }}$} & \multirow{2}{*}{$\mathrm{t}$} & \multirow{2}{*}{ Sig. } \\
\hline & & B & Std. Error & & & \\
\hline \multirow{2}{*}{1} & (Constant) & .176 & .052 & & 3.372 & .001 \\
\hline & $\mathrm{D}$ & .944 & .013 & .953 & 72.970 & .000 \\
\hline
\end{tabular}

a. Dependent Variable: IL

ANOVAa

\begin{tabular}{|ll|c|c|c|c|}
\hline Model & Sum of Squares & df & Mean Square & Sig. \\
\hline \multirow{3}{*}{1} & Regression & 491.199 & 1 & 491.199 & .046 \\
& Residual & 24.788 & 534 & $.000^{\text {b }}$ \\
& Total & 515.987 & 535 & \\
\end{tabular}

a. Dependent Variable: IL

b. Predictors: (Constant), S

\section{Coefficientsa}

\begin{tabular}{|c|c|c|c|c|c|c|}
\hline \multirow{2}{*}{\multicolumn{2}{|c|}{ Model }} & \multicolumn{2}{|c|}{ Unstandardized Coefficients } & \multirow{2}{*}{$\begin{array}{c}\text { Standardized Coefficients } \\
\text { Beta } \\
\end{array}$} & \multirow{2}{*}{$\mathrm{t}$} & \multirow{2}{*}{ Sig. } \\
\hline & & B & Std. Error & & & \\
\hline \multirow{2}{*}{1} & (Constant) & .127 & .037 & & 3.398 & .001 \\
\hline & $\mathrm{S}$ & .949 & .009 & .976 & 102.868 & .000 \\
\hline
\end{tabular}

a. Dependent Variable: IL

3. Simple regression of the relationship between Participative leadership style and instructional leadership.

Model Summary

\begin{tabular}{|l|l|l|l|l|}
\hline Model & $\mathrm{R}$ & R Square & Adjusted R Square & Std. Error of the Estimate \\
\hline 1 & $.975^{\mathrm{a}}$ & .951 & .951 & .21722 \\
\hline
\end{tabular}

a. Predictors: (Constant), $\mathrm{P}$

\begin{tabular}{|c|c|c|c|c|c|c|}
\hline \multicolumn{7}{|c|}{ ANOVA $^{a}$} \\
\hline & & Sum of Squares & $\mathrm{df}$ & Mean Square & $\mathrm{F}$ & Sig. \\
\hline \multirow{3}{*}{1} & Regression & 490.791 & 1 & 490.791 & 10401.972 & $.000^{\mathrm{b}}$ \\
\hline & Residual & 25.195 & 534 & .047 & & \\
\hline & Total & 515.987 & 535 & & & \\
\hline
\end{tabular}

a. Dependent Variable: IL

b. Predictors: (Constant), P

Coefficientsa

\begin{tabular}{|c|c|c|c|c|c|c|}
\hline & \multirow{2}{*}{ Model } & \multicolumn{2}{|c|}{ Unstandardized Coefficients } & Standardized Coefficients & \multirow{2}{*}{$\mathrm{t}$} & \multirow{2}{*}{ Sig } \\
\hline & & B & Std. Error & Beta & & \\
\hline \multirow{2}{*}{1} & (Constant) & .246 & .037 & & 6.707 & .000 \\
\hline & $\mathrm{P}$ & .946 & .009 & .975 & 101.990 & .000 \\
\hline
\end{tabular}

a. Dependent Variable: IL 
4. Simple regression of the relationship between Achievement-oriented leadership style and instructional leadership

Model Summary

\begin{tabular}{|c|c|c|c|c|}
\hline Model & $\mathrm{R}$ & R Square & Adjusted R Square & Std. Error of the Estimate \\
\hline 1 & $.918^{\mathrm{a}}$ & .844 & .843 & .38885 \\
\hline
\end{tabular}

a. Predictors: (Constant), A

ANOVAa
\begin{tabular}{|cc|c|c|c|c|}
\hline & Model & Sum of Squares & df & Mean Square & F \\
\hline \multirow{2}{*}{1} & Regression & 435.244 & 1 & 435.244 & .2878 .548 \\
& Residual & 80.742 & 534 & $.000^{\text {b }}$ \\
& Total & 515.987 & 535 & \\
\end{tabular}

a. Dependent Variable: IL

b. Predictors: (Constant), A

Coefficients $^{\mathrm{a}}$

\begin{tabular}{|c|c|c|c|c|c|c|}
\hline \multirow{2}{*}{\multicolumn{2}{|c|}{ Model }} & \multicolumn{2}{|c|}{ Unstandardized Coefficients } & \multirow{2}{*}{$\begin{array}{c}\text { Standardized Coefficients } \\
\text { Beta } \\
\end{array}$} & \multirow{2}{*}{$\mathrm{t}$} & \multirow{2}{*}{ Sig. } \\
\hline & & B & Std. Error & & & \\
\hline \multirow{2}{*}{1} & (Constant) & .740 & .061 & & 12.216 & .000 \\
\hline & A & .811 & .015 & .918 & 53.652 & .000 \\
\hline
\end{tabular}

a. Dependent Variable: IL

\section{Appendix F: Simple regression of leadership styles effect on the relationship between instructional leadership and Job Expectancy}

Simple regression between instructional leadership and Job Expectancy

\section{Model Summary}

\begin{tabular}{|c|c|c|c|c|}
\hline Model & $\mathrm{R}$ & R Square & Adjusted R Square & Std. Error of the Estimate \\
\hline 1 & $.897^{\mathrm{a}}$ & .804 & .804 & .48375 \\
\hline
\end{tabular}

a. Predictors: (Constant), IL

ANOVAa
\begin{tabular}{|ll|c|c|c|c|}
\hline Model & & Sum of Squares & df & Mean Square & F \\
\hline \multirow{3}{*}{1} & Regression & 513.658 & 1 & 513.658 & .234 \\
& Residual & 124.965 & 534 & $.000^{\mathrm{b}}$ & \\
& 638.623 & 535 & & \\
& Total & 6194.957 & \\
\end{tabular}

a. Dependent Variable: JE

b. Predictors: (Constant), IL

Coefficientsa

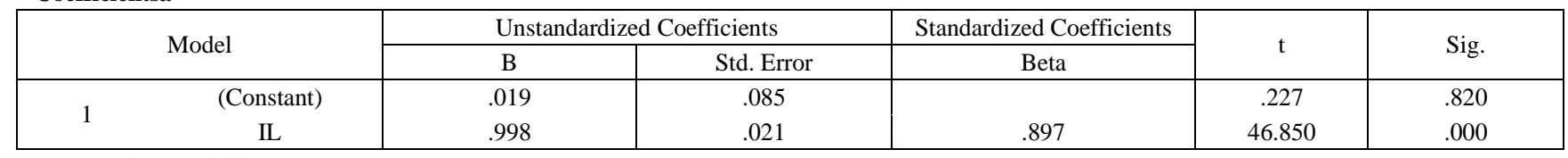

a. Dependent Variable: JE

Simple regression of Directive Leadership style affect on the relationship between instructional leadership and Job Expectancy

\section{Model Summary}

\begin{tabular}{|l|c|c|c|c|}
\hline Model & R & R Square & Adjusted R Square & Std. Error of the Estimate \\
\hline 1 & $.912^{\mathrm{a}}$ & .831 & .831 & .44944 \\
\hline
\end{tabular}

a. Predictors: (Constant), ILD

ANOVA ${ }^{\mathbf{a}}$
\begin{tabular}{|ll|c|c|c|c|}
\hline Model & & Sum of Squares & df & Mean Square & F \\
\hline \multirow{4}{*}{1} & Regression & 530.755 & 1 & 530.755 & 2627.500 \\
& Residual & 107.868 & 534 & .202 & $.000^{\text {b }}$ \\
& Total & 638.623 & 535 & & \\
\end{tabular}

a. Dependent Variable: JE

b. Predictors: (Constant), ILD 
Coefficientsa

\begin{tabular}{|ll|c|c|c|c|c|}
\hline \multirow{2}{*}{ Model } & \multicolumn{2}{|c|}{ Unstandardized Coefficients } & Standardized Coefficients & \multirow{2}{*}{$\mathrm{t}$} & \multirow{2}{*}{ Sig. } \\
\cline { 3 - 7 } & B & Std. Error & Beta & & & \\
\hline \multirow{2}{*}{1} & (Constant) & 1.965 & .042 & .000 & \\
& ILD & .028 & .001 & .912 & 51.259 & .000 \\
\hline
\end{tabular}

a. Dependent Variable: JE

Simple regression of Supportive Leadership style affect on the relationship between instructional leadership and Job Expectancy

\section{Model Summary}

\begin{tabular}{|c|c|c|c|c|}
\hline Model & $\mathrm{R}$ & R Square & Adjusted R Square & Std. Error of the Estimate \\
\hline 1 & $.913^{\mathrm{a}}$ & .834 & .834 & .44522 \\
\hline
\end{tabular}

a. Predictors: (Constant), ILS

ANOVAa
\begin{tabular}{|cc|c|c|c|c|}
\hline & Model & Sum of Squares & df & Mean Square & F \\
\hline \multirow{3}{*}{1} & Regression & 532.775 & 1 & 532.775 & .198 \\
& Residual & 105.848 & 534 & $.000^{\text {b }}$ & \\
& Total & 638.623 & 535 & & \\
\end{tabular}

a. Dependent Variable: JE

b. Predictors: (Constant), ILS

\section{Coefficientsa}

\begin{tabular}{|c|c|c|c|c|c|c|}
\hline & \multirow{2}{*}{ Model } & \multicolumn{2}{|c|}{ Unstandardized Coefficients } & \multirow{2}{*}{$\begin{array}{c}\text { Standardized Coefficients } \\
\text { Beta } \\
\end{array}$} & \multirow{2}{*}{$\mathrm{t}$} & \multirow{2}{*}{ Sig. } \\
\hline & & $\mathrm{B}$ & Std. Error & & & \\
\hline \multirow{2}{*}{1} & (Constant) & 1.971 & .041 & & 47.577 & .000 \\
\hline & ILS & .028 & .001 & .913 & 51.844 & .000 \\
\hline
\end{tabular}

a. Dependent Variable: JE

Simple regression of Participative Leadership style affect on the relationship between instructional leadership and Job Expectancy

Model Summary
\begin{tabular}{|c|c|c|c|c|}
\hline Model & R & R Square & Adjusted R Square & Std. Error of the Estimate \\
\hline 1 & $.908^{\mathrm{a}}$ & .825 & .825 & .45768 \\
\hline
\end{tabular}

a. Predictors: (Constant), ILP

ANOVAa
\begin{tabular}{|cl|c|c|c|c|}
\hline \multicolumn{2}{|c|}{ Model } & Sum of Squares & df & Mean Square & F \\
\hline \multirow{2}{*}{1} & Regression & 526.764 & 1 & 526.764 & .209 \\
& Residual & 111.859 & 534 & $.000^{\text {b }}$ & \\
& Total & 638.623 & 535 & \\
\end{tabular}

a. Dependent Variable: JE

b. Predictors: (Constant), ILP

Coefficientsa

\begin{tabular}{|c|c|c|c|c|c|c|}
\hline & \multirow{2}{*}{ Model } & \multicolumn{2}{|c|}{ Unstandardized Coefficients } & Standardized Coefficients & \multirow{2}{*}{$\mathrm{t}$} & \multirow{2}{*}{ Sig. } \\
\hline & & $\mathrm{B}$ & Std. Error & Beta & & \\
\hline \multirow{2}{*}{1} & (Constant) & 2.013 & .042 & & 47.909 & .000 \\
\hline & ILP & .028 & .001 & .908 & 50.147 & .000 \\
\hline
\end{tabular}

a. Dependent Variable: JE

Simple regression of Achievement- oriented Leadership style affect on the relationship between instructional leadership and Job Expectancy

Model Summary

\begin{tabular}{|c|c|c|c|c|}
\hline Model & $\mathrm{R}$ & R Square & Adjusted R Square & Std. Error of the Estimate \\
\hline 1 & $.900^{\mathrm{a}}$ & .809 & .809 & .47774 \\
\hline
\end{tabular}

a. Predictors: (Constant), ILA 


\section{ANOVAa}

\begin{tabular}{|cl|c|c|c|c|c|}
\hline & Model & Sum of Squares & df & Mean Square & F & Sig. \\
\hline \multirow{3}{*}{1} & Regression & 516.747 & 1 & 516.747 & 2264.127 & $.000^{\mathrm{b}}$ \\
& Residual & 121.876 & 534 & .228 & & \\
& Total & 638.623 & 535 & & & \\
\hline
\end{tabular}

a. Dependent Variable: JE

b. Predictors: (Constant), ILA

Coefficientsa

\begin{tabular}{|c|c|c|c|c|c|c|}
\hline & \multirow{2}{*}{ Model } & \multicolumn{2}{|c|}{ Unstandardized Coefficients } & Standardized Coefficients & \multirow{2}{*}{$\mathrm{t}$} & \multirow{2}{*}{ Sig. } \\
\hline & & B & Std. Error & Beta & & \\
\hline \multirow{2}{*}{1} & (Constant) & 2.061 & .043 & & 47.577 & .000 \\
\hline & ILA & .027 & .001 & .900 & 47.583 & .000 \\
\hline
\end{tabular}

a. Dependent Variable: JE

The author : Sabah Hejres

Sabah1966@hotmail.com

House :1401

Road: 4038

Block 240

Arad

Kingdom of Bahrain

Mobile: 39634436 